\title{
The Lagoon of Venice : the result of both natural factors and human influence
}

\author{
Oscar RAVERA \\ CNR - Istituto Italiano di Idrobiologia, Largo Tonolli 50, 28922 Verbania Pallanza, Italy \\ e-mail: o.ravera@iii.to.cnr.it
}

\begin{abstract}
This paper aims to present a picture of the lagoon of Venice and analyze the combined effects of natural factors and human influence on this fragile ecotone. The structure, functioning and evolution of the lagoon are illustrated. Under natural conditions, the solid load from the tributaries would transform the lagoon into dry land or, if the violence of the sea exceeded the solid load from the watershed, the lagoon would evolve into a marine bay. This natural succession has been hindered by the works undertaken by the Republic of Venice uninterruptedly through the centuries, because the lagoon environment was essential to the life and power of Venice. The effects of human activities from the beginning of the Venetian Republic to the present are described. In addition, the influence of socio-economic development on the lagoon area and, particularly, the impact of intensive agriculture and industrialization are discussed. A possible effect of eutrophication was the dramatic proliferation of the opportunistic macroalga Ulva rigida, which for about a decade played an important role in the physical, chemical and biological characteristics of the lagoon. At present, the most crucial problems of Venice and its lagoon are: the lowering of the level of the city in relation to that of the sea, the continuous decline in the number of inhabitants, the increasing frequency of the "high water" phenomenon, air and water pollution, and the increased erosion and salinity of the lagoon. The recent measures taken and those still to be applied for conserving and recovering Venice and its lagoon and, particularly, the works for preventing the risk of high water are compared. There is an evident need for a new type of socio-economic development in symbiosis with the environment and tradition of Venice.
\end{abstract}

Key words: lagoon ecotone, environmental resources, human influence, toxic and nutrient pollution, recovery measures

\section{GENERAL DESCRIPTION}

The Lagoon of Venice is a typical ecotone located between the land (terra firma) and the Adriatic Sea (Fig. 1). The lagoon ecotone is an open, complex, ordered and dynamic system. Open because it exchanges material and energy with both the limiting ecosystems (the sea and the watershed), complex, because several state variables are needed to describe it, ordered because the lagoon is not a homogeneous system but its various parts have different characteristics, and dynamic because the physical, chemical and biological characteristics vary continuously over time. The lagoon may be regarded as a reactor limited upwards and downwards by two interfacies (water/air and water/sediments) at which the exchanges of material and energy are particularly active.

Due to the low average depth of the Lagoon of Venice (about 1 meter), the productive layer (trophogenic layer) is in direct contact with (and not distinguishable from) that in which the activities of the decomposers are most active (tropholitic layer); this accelerates the biogeochemical cycle of the macro- and micronutrients between the sediments and the water column. This process, together with the nutrient load from its watershed and the sea and the internal load from the sediments, may explain why the production of the lagoon is higher than that of the sea and, in general, of the same order of magnitude as that of the eutrophic shallow lakes.
The Lagoon of Venice, like most lagoons, is liable to major and sudden variations and, consequently, its equilibrium is permanently unstable. This is the cause of its great changes, evolving either into a marine bay or, by a natural succession, through a salt-marsh environment, to dry land. As a consequence, on the geological scale, the life of a lagoon is always rather short. Indeed, the load of solid material discharged into the lagoon from its tributaries would bury it or, if the violence of the sea exceeded the solid load from the watershed, the sandbars protecting the lagoon would be demolished and the lagoon transformed into a marine bay. This would be the fate of the Lagoon of Venice without the uninterrupted work undertaken by the Serenissima Republic of Venice to arrest the processes of the natural succession. Thanks to this work, the lagoon has maintained its identity through the centuries.

The Lagoon of Venice is protected from the Adriatic Sea by sandbars (Cavallino, Lido and Pellestrina) which are interrupted by three inlets-opening (bocche $d i$ porto): Lido, Malamocco and Chioggia (e.g., Zille 1955). The water renewal of the lagoon is maintained by the tide cycle (the ebb and flow of the tide) through the three inlets. Water renewal is essential for the lagoon's metabolism. For example, a considerable increase of the water renewal-time, maintained for an adequate period of time, would increase the variation of the salinity during the year due to rainfall distribution, evaporation and the water load from the watershed. In summer, the fast decomposition rate of the organic substance, with a 


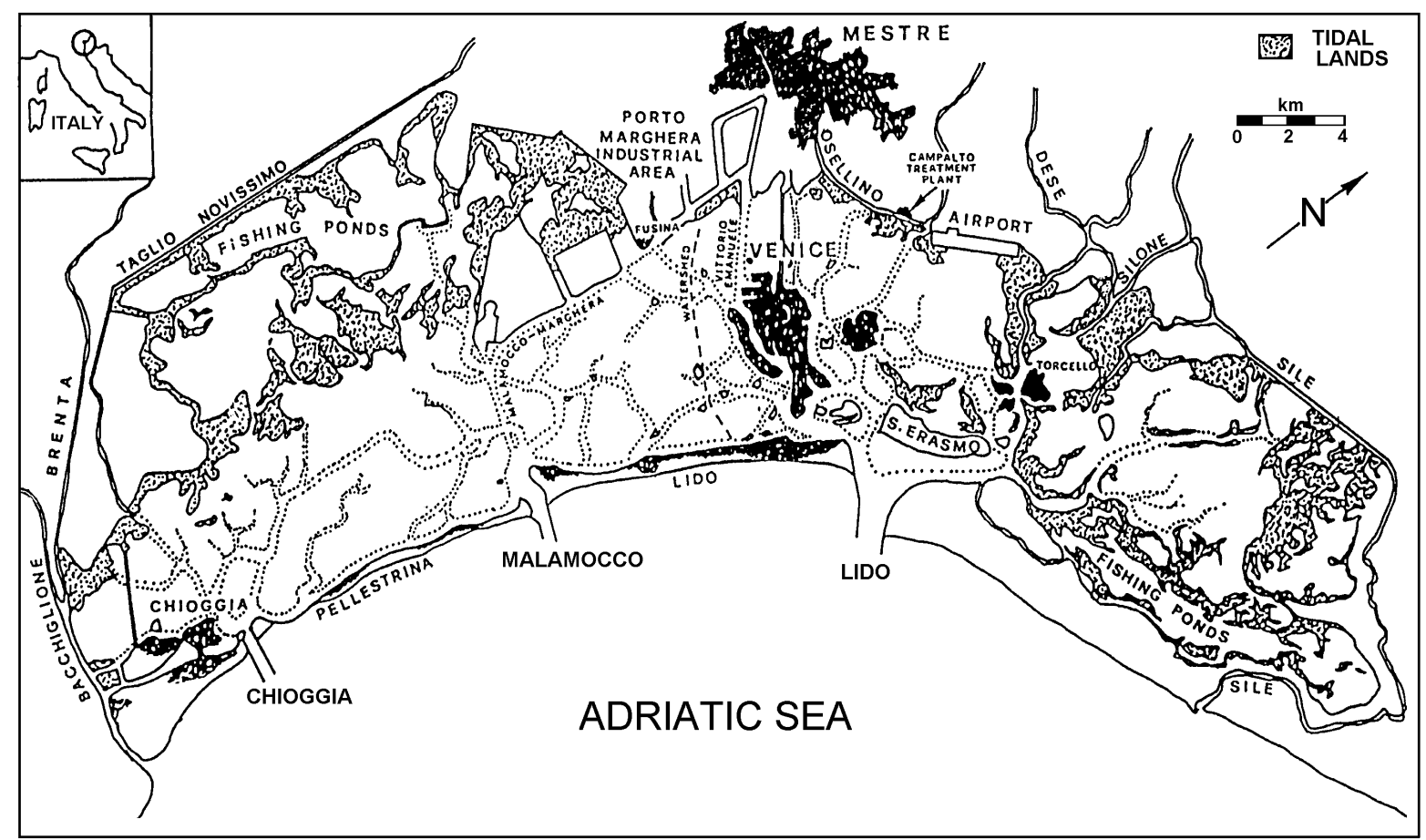

Fig. 1. Lagoon of Venice. The lagoon has a length of $55 \mathrm{~km}$, a maximum width of $15 \mathrm{~km}$, a surface area of $550 \mathrm{~km}^{2}$ and its watershed is $1800 \mathrm{~km}^{2}$.

consequent consumption of oxygen, would cause anoxic conditions in most of the lagoon; in addition, nutrients and toxic pollutants could be accumulated. The water quality would decline and the combined effects of these dangerous variations on the plant and animal populations would soon be evident. As a result, only a few tolerant and opportunistic species would become very abundant and replace the most sensitive ones, causing a progressive decline in species diversity. It would also be easy to predict dangerous consequences for the economy and quality of life of the inhabitants of Venice and the islands of the lagoon .

The contrasting influences exerted on the lagoon by the watershed and the sea create suitable conditions for producing gradients of some physical and chemical variables, such as water movement, salinity and nutrient concentrations, giving rise to a pattern of species distribution in agreement with the "continuum" of Whittaker's theory. Although this is fairly evident for certain species, the distribution of physical, chemical and biological variables is more similar to a "mosaic" pattern due to the complex morphology of the lagoon bottom and the consequent irregular hydrology. In some cases this mosaic structure is enhanced by the aquatic vegetation. For example, during the bloom period of Ulva rigida (in the 80s), in those areas which were most suitable for its proliferation, favoured by the slow water renewal, a peculiar microenvironment developed with physical, chemical and biological characteristics different from those of the surrounding environment.

About a quarter $\left(140 \mathrm{~km}^{2}\right)$ of the total lagoon surface is occupied by mud flats which form marshy areas (barene), emerging from the water only during low tide. The barene located along the canals were built up with the sediments removed from the canal bottom by the tide current, whereas the other barene originated from the accumulation of the solid material transported by the tributaries. The surface area of the barene varies from a few square meters to several hectares, and their distribution is very irregular. The barena is a peculiar ecosystem characterized by plant and animal species adapted to the continuous alternation of high with low salinity and of dryness with wetness. During the high tide the barena adsorbs a huge volume of water which is in part released during the low tide period. Consequently, the barena, by acting as a sponge, has a certain regulatory effect on the water level of the lagoon.

Another characteristic of the Lagoon of Venice consists in its numerous islands, many of them located in the central basin of the lagoon. The total area occupied by the islands amounts to $40 \mathrm{~km}^{2}$. The islands were built up by various processes: a) the sediments, eroded from the lagoon bottom and littoral zone, were accumulated on barene by waves and currents; b) the sedimentation of solid material transported by the tributaries in areas with slow water renewal and c) both these processes 
may have combined to build up the island. In addition, human intervention has enlarged, consolidated or completely built up several islands with rocks, piles, hurdles and solid waste, such as the Island of Sacca Sessola (16 ha) in 1870 and the Island of Tronchetto (18 ha) in 1960. Towns were founded on some islands (e. g., Venice, Murano, Burano), on others lazarets, monasteries, hospitals, and charitable institutions were built, and during the Napoleonic dominion a series of small islands were used as redoubts. At present, most of the islands are deserted and more or less in a state of neglect. The islands exert a certain influence on the hydrology and the sediment distribution of the lagoon; in addition, they enlarge the environment suitable for settlement by littoral communities by increasing the surface area of the total littoral zone.

As an effect of subsidence, the Adriatic coasts are slowly but steadily sinking. The loads of solid material from the rivers flowing into the Adriatic Sea are distributed along the coast by the currents and amply counterbalance the coastal lowering rate. As a result, the Adriatic littoral zone is continuously advancing towards the sea. Conversely, in the Lagoon of Venice the subsidence effect is not offset by sediment accumulation because of the anthropogenic diversion outside the lagoon of its most important tributaries. The natural subsidence seems to be aggravated by ground water and natural gas extractions from the lagoon area; this exploitation was at its height from 1930 to 1970 . In addition, during the last five centuries the sea level has been rising slowly, but continuously (eustatism). The subsidence and eustatism processes combine to lower the level of Venice in relation to that of the sea; this is a source of permanent risk for Venice and the other urban centers of the lagoon, which are flooded with increasing frequency (e.g., Rusconi 1983; Camuffo 1993; Cecconi et al. 1998). The most recent estimation of the rise in sea level (taking into account subsidence and eustatism) ranges from 13 to $15 \mathrm{~cm}$ in a century (Report of the Committee of international experts, 1998; Fig. 2).

\section{ENVIRONMENTAL RESOURCES}

Although fishing in the lagoon has progressively declined since the XVIII century, it still has a certain economic importance today. It is one of the most traditional activities of the local population, although nowadays the methods, equipment and boats of the past have been more or less modified or substituted by new ones (e.g. Brunelli, 1940; Rallo, 1992).

Lagoon fish fauna shows a great variety of species, but those which are exploited commercially are rather few: dory (Sparus auratus), bass (Dicentrarchus labrax), five species of mullets (Mugil cephalus, Chelon labrosus-chelo, Liza aurata, L. ramada capito and $L$. saliens) and eel (Anguilla anguilla). These species are euryhaline and to complete their life-cycle migrate be-

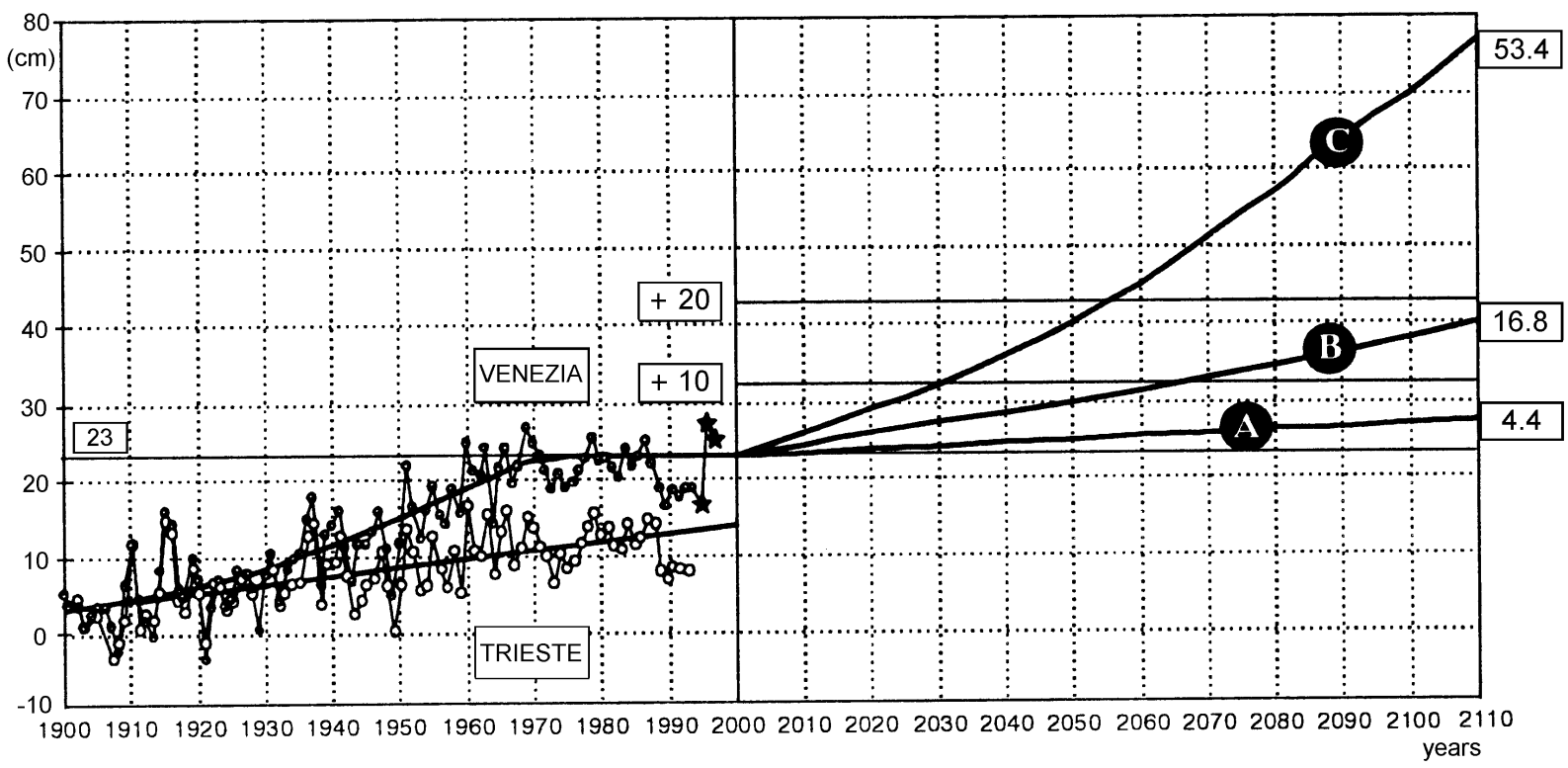

Fig. 2. Sea level rise scenarios and comparison with measured levels in the past century (reproduced From EIS, Section C, Vol. 1, 1997). The star marks in the record of Venice indicate the most recent measures (Cecconi et al. 1998). Scenario A (4.4 cm rise in the next 110 years) is based on the assumption that long-term eustatism has stopped and the long-term geological subsidence is the only process contributing to relative sea level rise. Scenario B (16.8 cm for the next 110 years) is based on the assumption that long-term eustatism and long-term geological subsidence will continue as they did over the last few hundred years. Scenario C $(53.4 \mathrm{~cm}$ for the next 110 years) incorporates additional sea-level rise as a result of (human induced) climate change (Report on the mobile gates project, August 1998, by the Committee of the international experts). 
tween the lagoon and the sea. The migration period varies with the species in relation to their food and temperature requirements, but, generally they spend the summer in the lagoon, where food is very plentiful. The most fruitful period for fishing is the end of summer and the beginning of autumn, when the fish, after reaching commercial size, migrate to the sea.

Apart from fish, bivalve molluscs are another important resource, with the annual yield amounting to 50,000 tons (Pellizzato 1996). The most important commercially are the bivalves (Mytilus galloprovincialis, Ostrea edulis, Crassostrea gigas angulata, Tapes decussatus, T. philippinarum, Cerastoderma glaucum). Some Cephalopods (Sepia officinalis and Eledone moschata) and Gastropods (Bolinus brandaris and Aporrais pes-pelicani) are locally important. At the end of the $80 \mathrm{~s}$ an Asiatic clam (Tapes philippinarum ) was successfully introduced and in 1966-1967 the Portuguese oyster (Crassostrea angulata), probably from Japan. Other allochtonous species of molluscs introduced into the lagoon did not produce the expected results (e.g., Cesari $\&$ Pellizzato 1985). In various areas of the lagoon there are blue-mussel (Mytilus galloprovincialis) farms. In recent years both the species of Tapes (philippinarum and decussatus) have been collected by hydraulic dredges. There is evidence that this practice damages the benthic fauna and profoundly influences the exchange of substances between water and sediments.

Crustacean species (Crangon crangon, Palaemon elegans, $P$. serratus and Carcinus mediterraneus) are much prized, but their yield is very small if compared to those of molluscs and fish.

Vallicoltura is a type of aquiculture peculiar to the Venice Lagoon (e.g., Bullo 1940a, b; Ravagnan 1980). The valle is a portion of the lagoon, shallow and limited by the littoral zone and banks, which are more or less complete, and separate the valle from the lagoon. There are several types of valli; some, generally located near the inlets connecting the lagoon with the sea, were until the last century open or embanked with fences of hurdles, whereas others, located near the littoral, were up to XVIII century completely embanked. In the 40 s almost all the valli were embanked, with some inlets permitting the water to flow between the valle and the lagoon. This type of aquiculture, which was very developed during the Middle Ages, has been modified in the XIX century, with, for example, a canal around the valle and ponds for fish-wintering.

The practice of vallicoltura is based on fish migration. In spring the young fish migrate from the Adriatic to the lagoon and some of them end up in the valli; in autumn, the fish, grown larger during the summer spent in the valli, migrate to the lagoon and then to the Adriatic to reproduce. During their passage from the valle to the lagoon, the fish are caught by the traditional hurdle system.
In the past the spring migration of young fish into the valle was the sole source of repopulation; now, to increase production, most of the valli are repopulated by fingerlings obtained by fishing or, more commonly, by fish farms. Most of the yield consists of the same species as are important in traditional fishing, that is, dory, bass, mullets and eel. The yield ranges from 50 to 150 $\mathrm{kg} \mathrm{ha}^{-1}$, depending on the characteristics of the valle and its management. At present the total surface area taken up by the valli, although smaller than that occupied during the XIX century, amounts to ca. 9000 ha. The abundance and variety of non-migratory and migratory birds found in the valli is the result of their environmental variety, the low pollutant level and the minimum human disturbance. In conclusion, the valle is a distinctive landscape built up by man consisting of a productive and complex system with high biodiversity, the consequence of the great variety of environments distributed in a small area; for example, canals, brackish and freshwater ponds, and sandbanks (Ravera 1999).

Hunting, as a source of food as well a sport, was an important part of the life of the lagoon people. Until the end of the Middle Ages much of the land bordering on the lagoon was covered by woods, protected since 1282 by severe legislation. A variety of mammals (for example, wild boar, wolf, fox, deer, wild goat) and birds lived in these woods (Zanetti 1995a). At present, hunting is generally pursued as a sport and mostly involves aquatic birds. The progressive decline of the bird population is the consequence of wetland reclamation, hunting, and the noise of motor boats.

\section{THE IMPACT OF MAN UP TO THE XIX CENTURY}

From its foundation the Republic of Venice had two fundamental needs: a) to maintain a water way connecting the city with the Adriatic Sea, essential for its Mediterranean trade, and b) to protect the city from the violence of the sea and from its enemies. The Venetian government always considered both of these objectives to be of great importance for the survival and power of the Republic. The location of Venice, built up on islands set in the central area of the lagoon, assured its defence against the assaults of enemies from land and sea. As a consequence, the lagoon had to maintain its identity by hindering its natural evolution either into a marine or a land environment.

Much work in pursuit of this aim has been done and very strict legislation applied to decrease silting by the tributaries, to protect the lagoon from erosion by the sea and to maintain an active circulation of water in the lagoon and communication with the sea. The load of solid material from the tributaries could, in the course of time, fill the lagoon; this process has been progressively accelerated by the increased erosion of the watershed caused by the clearing of forest land given over to pas- 
ture and crops, and the felling of trees for the wood used as building material and fuel (Perlin 1991).

To prevent the lagoon filling up, the main water courses were diverted outside the lagoon from the XV to the XVII century; for example, the rivers Brenta, Marzenego, Bacchiglione and Piave. These works, in addition to reducing silting, had three main consequences on the lagoon: a) the salinity progressively increased, as a result of the reduced freshwater load ; in fact at present, most of the lagoon has salinity values of the same order of magnitude as those measured in the Adriatic Sea (30-33\%o) except in the area near the inner coast; b) the nutrient loads, and particularly that of phosphorus, decreased as a consequence of the reduced input from the terra firma and c) the reduced silting no longer compensated for the subsidence rate, so that the mean depth of the lagoon and the erosion increased and the lagoon bottom became more flattened. Unfortunately, there is no satisfactory information on the effect these environmental alterations have had on the biological communities.

To protect the lagoon from the violence of the sea, the efficiency of the natural barriers (sandbars) was improved with various works. For example, after 1282 the burning or felling of trees growing on the littoral was forbidden, as was the removal of sand from the same zone after 1334. By the middle of the XIV century, the littoral zone of the sandbars had been protected with chalk boulders set in the areas most exposed to waves and currents, and the dunes were consolidated and protected against the winds with tamarisk (Tamarix gallica) plantations. Because the sandbars were not adequately protected by the chalk boulders, hurdles and piles, in 1740 at Malamocco and Pellestrina construction work started on the murazzi, which are walls made of Istria rocks cemented together to form an adequate barrier against the sea.

Various interventions have been aimed at increasing the water circulation in the lagoon; for example, several unauthorised works have been removed and in 1661, to increase the surface area of the lagoon, some fish farms (valli) and some salt marshes were flooded.

These are only a few examples of the short and long term measures taken to protect the lagoon from both silting and the sea.

Until the XIII and XIV centuries the greatest economic resource of Venice was trade; only later did industry start to prosper, although various crafts had been practised since the XI century. Silk, wool, fur and leather goods; crafted products in precious metal and glass; dyes, sugar, wax and soap, were the most highly regarded goods manufactured by Venice. To prevent pollution and/or fire, some industries were located on the islands (e.g., glass factories on Murano, leather and fur on the Giudecca) and others (e.g., dye works) had since 1485 been regulated by the Provveditori alla
Sanità (Health Superintendents) with strict rules against air and water pollution (Ciriacono 1995).

In the XVI and the XVII centuries Venice had to face increasing economic competition with some industrialized countries (e.g., Holland, England, France). Some Venetian industries were hampered by the peculiar location of the city; for example, fresh water was scarce and the transport of raw materials (e.g., wood) was costly. As a consequence of the deforestation of the lagoon watershed, the cost of timber increased progressively along with its scarcity. This is the main reason why from the end of the XVI century many shipowners preferred to buy vessels built abroad rather than in Venice. In fact, at the end of the XVII century $80 \%$ of the commercial vessels flying the Venetian flag were built abroad (Perlin 1991). In addition, the high cost of skilled workers, the strict legislation to protect human health and the environment, and the less advanced technology than that of its foreign competitors, negatively influenced the economy of Venice. In spite of these difficulties, Venetian industries, and particularly those producing luxury and fine goods (e.g. books, scientific instruments, glass-works, furniture, mirrors) survived until the fall of the Venetian Republic in 1797. This may be explained by the consistent local demand for goods, the high standard of living and demographical stability (Ciriacono 1978; 1995). At the beginning of the XIX century Venetian industry suffered its most serious crisis in the history of the city and, consequently, the economic policy of Venice was profoundly modified.

\section{THE INFLUENCE OF MAN FROM THE XIX CENTURY TO THE PRESENT}

Since the XIX century new development models, commonly adopted in Europe and North America, have been applied to Venice and its lagoon to enhance its agriculture and industry.

During the Napoleonic dominion (1806-1814), there was a clear intention to bring Venice into line with other cities; for example, a canal was covered over and made into a wide street, the Via Eugenia (now Via Garibaldi), named in honour of Eugène de Beauharnais, viceroy of Italy; and public gardens, called the Giardini Napoleonici (Napoleonic Gardens), were laid out. On the other hand, the legislation governing the waters of the Venetian Republic was kept and measures undertaken to conserve the lagoon and enhance economic development.

Under Austrian rule (1814-1866), the construction of the railway bridge connecting Venice to the terra firma (1846), reduced the city's insularity. Another one was subsequently built alongside the first for motor traffic, originally called Bridge of the Littorio (1933) and now Liberty Bridge (1945). The passage of modern ships of great tonnage required deeper inlets between the sea and the lagoon. To satisfy this requirement, two outer dykes at the Malamocco inlet were built between 1838 and 
1853. As a result, the width of the inlet decreased, with a consequent increase in the velocity of tidal currents, which caused an increase in the depth of the inlet. Between 1881 and 1905 two outer dykes were built for the same purpose at the Lido inlet, and at the Chioggia inlet the outer dykes were completed in 1934. verted to solid land. This caused a further reduction of the lagoon area, after the reduction due to the reclamation of land for agriculture and industry which amounted to 3280 ha during the period from 1924 to 1960.

The chemical and petrochemical industry of Mar-

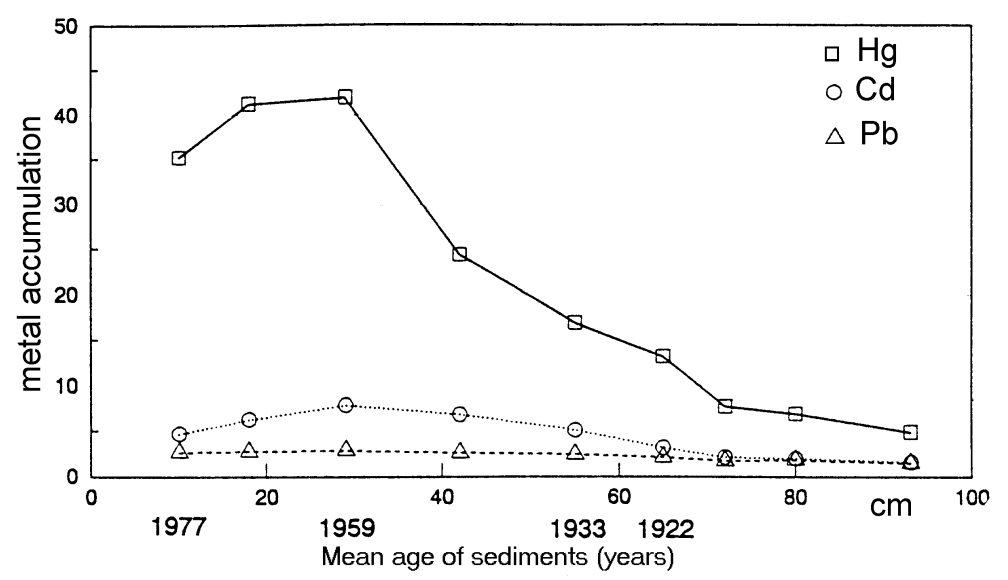

Fig. 3. Vertical distribution of the metal accumulation values in a sediment core collected from the industrial area of the Venice lagoon. The metal accumulation is expressed by the ratio between the metal concentration in the sediment (dry weight) and its background value (i.e. the metal concentration measured in the deepest layers of the core corresponding to the time period before the industrialization age) (Pavoni et al. 1992).

After the annexation of Venice to the Italian Kingdom (1866) a new model was planned to stimulate the economy of the city. This plan involved extending Venice to the terra firma keeping separate its different rôles: the ancient city as a residential, touristic and cultural centre, and the terra firma (Marghera, Mestre) as an industrial port (Soriani $1995 \mathrm{a}, \mathrm{b}$ ). Works to transform the three inlets of St. Nicolò, St. Erasmo and Treporti into the sole inlet of the Lido were completed at the beginning of the XX century. In 1870, construction work on the commercial port of St. Marta was started, and in 1917 it was decided to build the industrial port of Porto Marghera, necessary for the development of the $1^{\text {st }}$ industrial area and destined in particular to be a centre of the iron and metallurgical industry. The Vittorio Emmanuele III Canal was dug in 1920-1930 to connect the industrial port of Marghera with the Giudecca Canal. To allow the huge oil tankers access to Marghera harbour from the Malamocco inlet, the Canale dei Petroli (Oil canal) was dug in1965-1969: this work required the removal of about 25 million cubic meters of sediment. The Canale dei Petroli enhances the impact of the tidal current from the sea with a consequent increase in the erosion of the lagoon. The beginning of the $60 \mathrm{~s}$ saw the development of the second industrial area in Marghera with plans for a third one. The dangerous consequences of these developments for the environment and the pollution risk to the inhabitants of the area and the historic monuments of Venice soon became evident ; as a result, the third industrial area was not built (Fig. 3). Unfortunately, a great part of the area originally allotted to this industrial development (4000 ha), which was covered by barene, had already been con- ghera, which in the 50s and 60s was one of the most important in Italy, has been in continuous decline from the 70 s up to the present.

In the XX century agriculture has also been profoundly modified by the transformation from traditional to industrial methods. Since Roman times agriculture has been practised on the coasts and islands of the lagoon. Cultivated species were transferred from the terrafirma to the lagoon environment, which is characterized by scarce fresh water, winds and silty and clayey soil rich in marine salts. These factors combined to select species with a great capacity for adaptation. Several species of vegetables and fruit-trees are typical of the environment and are the main products of the agriculture of the Venice lagoon (Zanetti 1995b). In recent times large areas of the lagoon border have been reclaimed to be cultivated with monocoltures; for example, 2300 ha were allotted to agriculture in 1924. Industrialized agriculture needs fertilizers, biocides, irrigation and fuel, which have a more or less marked impact on the lagoon environment.

The development of industry and the use of fertilizers and biocides in agriculture are the main causes of air and water pollution in the lagoon (Tab. 1). In recent decades, in some areas of the lagoon, organic and inorganic toxic pollutants have been accumulated in the surface sediments (Orio \& Donazzolo 1987). The potential risk of oil pollution is increased by the use of oil-tankers of great tonnage, which increased very rapidly in the $60 \mathrm{~s}$. In recent years the annual transport of oil and liquid chemical products has amounted to about 12 million tons. 
Tab. 1. Concentrations (ng $\mathrm{g}^{-1}$ dry weight of tissues) of halogenated hydrocarbons in organisms collected from industrialized and non-industrialized areas of the Venice lagoon. $\mathrm{P}=$ pisces; $\mathrm{C}=$ crustacea; $\mathrm{M}=$ mollusca; $\mathrm{A}=\mathrm{algae}$. (from: Pavoni et al. 1992).

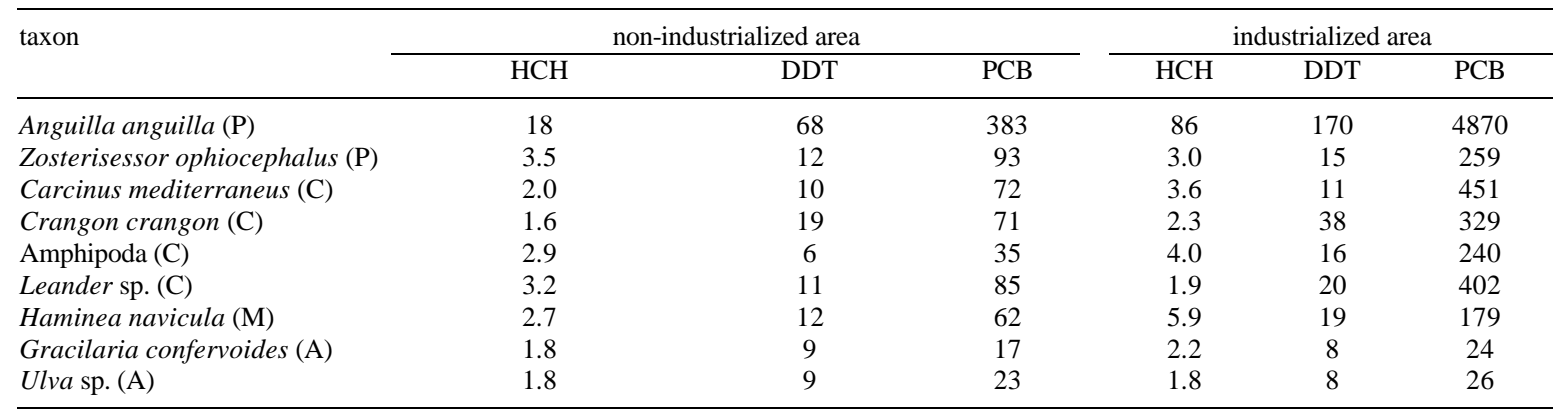

Domestic sewage, rich in algal nutrients (e.g., phosphorus and nitrogen compounds), must be added to these pollutant loads. Even now the untreated sewage produced by the inhabitants of Venice and its numerous tourists (about twelve million annual presences) is directly discharged into the city's 180 canals (called rii) and then dispersed in the lagoon by the tidal cycle (Tab. 2).

Tab. 2. Concentrations ( $\mu \mathrm{g} \mathrm{g}^{-1}$ dry weight) of organic micropollutants in surface sediment of the Venice canals. $\mathrm{PAHs}=$ polycyclic aromatic hydrocarbons, $\mathrm{PCBs}$ $=$ polychlorinated biphenyls, chlorinated pesticides $=$ DDT and its metabolites (Pavoni et al. 1998).

\begin{tabular}{lcc}
\hline micropollutant & $\mathrm{x} \pm \mathrm{SD}$ & range \\
\hline PAHs & $11 \pm 18$ & $0.57-65.0$ \\
PCBs & $0.3 \pm 0.2$ & $0.07-0.63$ \\
Chlorinated pesticides & $0.06 \pm 0.07$ & $<0.001-0.259$ \\
\hline
\end{tabular}

In the lagoon waters the concentration of phosphorus compounds, although always higher than that in the Adriatic Sea, is generally less than $20 \mu \mathrm{g} \mathrm{l}^{-1}$, whereas nitrogen compounds, and particularly nitrate and ammonia, reach rather high concentrations. Bendoricchio (1996) estimated for the lagoon watershed that the mean annual production of nitrogen and phosphorus is of $9350 \mathrm{t}$ and $1300 \mathrm{t}$ respectively. The most recent evaluation (Consiglio Regionale Veneto 1998 and Regione Veneto, 1998) is that the annual loads of nitrogen and phosphorus entering the lagoon amount to $6650 \mathrm{t}$ and $683 \mathrm{t}$ respectively. By comparing the values of the loads with those of the production for both nutrients, it results that $71 \%$ of the nitrogen and $53 \%$ of the phosphorus produced are released into the lagoon (Tab. 3). It is predicted that the measures already taken and those still to be applied will reduce the nitrogen load to $4500 \mathrm{t}$ and that of phosphorus to $420 \mathrm{t}$ by 2003 .

In spite of the high concentration of nutrients in the lagoon water, before the 70 s there did not seem to be any dramatic effects of eutrophication (Cossu \& De Fraja Frangipane 1985). Great changes in the structure of the macrophyte association were observed by Sfriso (1987) comparing the species abundances from 1978 to
1984 with those reported by Pignatti (1962) for the 60s. The major differences were the great increase in the nitrophylic Ulvales (Ulva, Enteromorpha) and the progressive decrease in the Phanerogames: Zostera noltii and Z. marina.

During the 80s the bloom of Ulva rigida, Agard. had a dramatic effect on the lagoon ecosystem and represented an important nuisance to man and his activities (e.g. problems for navigation, bad smell, sulphydric acid emission, mass mortality of fish). The biomass of this green macroalga, in certain areas with a slow water renewal, reached values higher than $10 \mathrm{~kg} \mathrm{ww} \mathrm{m}^{-2}$. Ulva was partly harvested each year during this period; for example, in 1987, 10,200 tons of the alga were removed from the lagoon (Solazzi et al. 1991).

Many scientists believed that the most important cause of the Ulva bloom was probably the increased load of nutrients, and particularly nitrogen compounds, reaching the lagoon. Apart from the nutrient load, there are other, no less important, causes such as the works which have modified the hydrological and morphological characteristics of the lagoon (e.g., deepening of inlets, digging of canals), and subsidence and eustatism (Solazzi et al. 1991). At the same time as the Ulva bloom appeared, there was a great increase in numbers of the midge Chironomus salinarius. This insect attained a population density as high as 25,000 larvae $\mathrm{m}^{-2}$ (Pavoni et al. 1992). This insect probably increased in abundance both because of the enrichment of the sediment with organic matter produced by the decaying Ulva, and because of the reduced competition with other benthic species which had declined as a result of oxygen depletion due to Ulva decomposition. Indeed, because of the haemoglobin content in the haemolymph of the $C$. salinarius larvae, they need very low oxygen concentrations. During the emergence of this insect, the enormous number of adults led to the Liberty Bridge becoming so slippery as to cause several car accidents.

During its spring growth, Ulva concentrates in its thallus great amounts of several elements; for example, the concentration factor for nitrogen exceeds the value of 5000 and that of phosphorus 12,000, if compared with the concentrations in the water. In areas with very 
Tab. 3. Nutrient loads (tons year ${ }^{-1}$ )which reach the lagoon (from Consiglio Regionale Veneto, 1998; and Regione Veneto, 1998), not including atmospheric input of $740 \mathrm{t}$ nitrogen and $66 \mathrm{t}$ phosphorus.

\begin{tabular}{lccccc}
\hline & Nitrogen & Nitrogen & Nitrogen & Phosphorus & Phosphorus \\
& 1994 & 1998 & 2003 & 1998 & 2003 \\
\hline urban & 3000 & 2300 & 1350 & 359 & 246 \\
urban (diffuse) & 700 & 450 & 300 & 110 & 87 \\
industrial & 850 & 850 & 850 & 79 & 80 \\
livestock & 2300 & 2300 & 1600 & 469 & 319 \\
agriculture & 2700 & 3400 & 3300 & 102 & 98 \\
total load & 9550 & 9300 & 7150 & 1119 & 830 \\
self depuration & -2700 & -2650 & -2100 & & \\
diversion/remediations & - & - & -550 & & 420 \\
total load reaching the lagoon & 6850 & 6650 & 4500 & 683 & \\
\hline
\end{tabular}

abundant Ulva the oxygen saturation of the water attained values as high as $300 \%$, as a result of the photosynthesis of the macroalga. During the late summer, in the same areas, when the decomposition of Ulva attained its maximum, the oxygen consumption was so high that anoxic conditions were produced, with the consequent decline of the benthic populations and the elimination of the most sensitive species. During the first few days of decomposition of Ulva, a high percentage of the elements composing its thallus was released; first phosphorus, then nitrogen and sulphur, and finally carbon. (Tab. 4).

Tab. 4. Element loss from Ulva rigida thallus calculated on the data from field experiments. The winter experiment lasted 16 days; the summer experiment 3 days. Initial concentration and amount of element released are expressed in g element $100 \mathrm{~g}^{-1}$ d.w. (Ravera et al. 1998).

\begin{tabular}{ccccc}
\hline${ }^{\circ} \mathrm{C}$ & element & $\begin{array}{c}\text { Initial } \\
\text { concentration }\end{array}$ & \% Release & Amount released \\
\hline \multirow{2}{*}{8.4} & $\mathrm{C}$ & 35.64 & 68.8 & 24.52 \\
& $\mathrm{~N}$ & 4.46 & 58.0 & 2.59 \\
& $\mathrm{P}$ & 0.21 & 84.8 & 0.18 \\
& $\mathrm{~S}$ & 2.60 & 67.6 & 1.76 \\
& $\mathrm{C}$ & 35.79 & 73.9 & 26.45 \\
& $\mathrm{~N}$ & 4.62 & 73.7 & 3.40 \\
& $\mathrm{P}$ & 0.20 & 91.5 & 0.18 \\
& $\mathrm{~S}$ & 3.18 & 56.4 & 1.80 \\
\hline
\end{tabular}

These considerations show clearly that Ulva, during its proliferation as well as its decay, has a profound effect on the physical environment and, consequently, on the entire community. If the Ulva proliferation was probably an effect of the increased nutrient enrichment and the alterations of the hydrology and morphology of the lagoon, it is very difficult to explain why at the beginning of the 90s the species progressively declined, and why at the same time the abundance of $C$. salinarius also showed a marked decrease. It is interesting to note that up to now Ulva has not been replaced by other algal blooms of equivalent importance, and the decrease of nutrient concentrations in the water, the effect of effluent treatment at the border of the lagoon, is not so marked as to justify the decline of this opportunistic species.

The main sources of air pollution are industrial emissions (e.g., from oil refineries), domestic heating and motor navigation. The annual deposition of nutrient substances from the atmosphere to the lagoon has been evaluated at $740 \mathrm{t}$ of nitrogen and $66 \mathrm{t}$ of phosphorus. The sulphur content in fossil fuels is the source of the sulphurous anhydride and thus of the acid depositions which are not only dangerous for human health, but also damage the historic monuments and artistic masterpieces which are the treasures of Venice. The city is at least partly protected from damage from acid deposition by winds which prevent thermic inversion for most of the year, and particularly by the bora (wind blowing from the north-east), which is rich in chalk dust transported from the rocks of the Carso region. Because of the great buffering capacity of the sea water, no evident effects from acid depositions have been recorded in the lagoon. In the 80s, when at the end of summer the decomposition rate of Ulva rigida was very high, a huge amount of organic and inorganic sulphur compounds was released from its thallus into the atmosphere via the water, producing marked temporary acid depositions. Indeed, the mean concentration of total sulphur in Ulva is very high ( $36 \mathrm{mg} \mathrm{g}^{-1}$ dry weight) compared with that measured in Zostera $(6 \mathrm{mg})$ and in benthic animals (from 7 to $16 \mathrm{mg}$ ) (Ravera et al. 2000).

\section{RECENT MEASURES TO SAVE VENICE AND ITS LAGOON}

During recent years, as a result of both the decline of industry and the implementation of stricter legislation aimed at reducing air and water pollution, the concentrations of nutrient and toxic substances in the environment have decreased.

To protect the lagoon from the violence of the sea, the murazzi, seriously damaged by storm surge on November 4, 1966, were restored at the beginning of the 90 s, new sea-shores built up and those eroded enlarged. To reduce the risk of subsidence in the lagoon area, methane extraction and the drilling of new artesian 
wells has been forbidden, and the quantity of water taken from the pre-existing wells reduced. The water supply requirements of the industries at Marghera have been met by the River Sile. To counter the consequences of erosion (sediment loss and the bottom flattening), barene are being built up with sediments dredged from the canals. By this technique, during the last decade, 400 ha of barene have been restored with an annual reduction of sediment loss to the sea of about $400,000 \mathrm{~m}^{3}$. Under the Venetian Republic the city canals were periodically dredged to prevent the excessive accumulation of sediments and activate the circulation of tidal currents, with a consequent cleaning of the canals. In the last few years, after about fifty years with no intervention, the dredging of the canals of Venice has started again.

The necessity for protecting Venice and its lagoon from the high water became clear after an evaluation of the damage caused by the dramatic stormy sea of November 4, 1966, when the water level of the lagoon reached about 2 meters above the reference value. As a consequence of this damage to people, buildings and monuments, special laws were passed to save Venice and some short term measures have been taken. Because it is probable that in the near future the sea level, compared to that of the land, will continue to rise, as a combined effect of subsidence and eustatism, the prediction is that Venice and the other urban centers on the lagoon will be flooded more often (Tab. 5). and its environmental compatibility. The conclusions reached by these scientists and reported in the "Report of the committee of experts group, 1998" are here summarized: a) The insulae project cannot give protection against exceptional high tides, but may be useful against moderate ones, if the works are extended to all the lowlying parts of Venice and the other urban centres. On the other hand, this plan is very costly and its implementation would require a relatively long time. b) The renaturalization of the lagoon might be improved by the restoration of the barene and the construction of new ones, but they have little effect against high tides. c) Flooding all the fish farms would reduce the mean tidal peaks by less than two centimeters. d) The reduction of the inlet cross section and modifying the endsections of the breakwaters could not reduce the tidal peaks by more than few centimeters and would create considerable problems for navigation and, consequently, for the activity of the port. e) Refilling the "Oil Canal" connecting Malamocco inlet to Marghera harbour might decrease the tidal peaks only by a few millimeters. f) In several cases, coastal areas and urban centers have been protected from storm floods with barriers (e.g., the Thames and the Scheldt).

Unlike these barriers, the proposed gates are submerged and are raised only when the storm tide is above a pre-established level. Navigation is therefore interrupted only during the storm tide. For the present sea level situation, the annual closure frequency of the gates

Tab. 5. Annual frequency of floading in historic centers as a function of tidal level (reproduced from EIS, Section C, Volume 1, Tab. C3.1.1.3, page 143).

\begin{tabular}{cccc}
\hline Tidal level $(\mathrm{cm})^{*}$ & $\begin{array}{c}\text { Venice } \\
\text { Mean frequency }\end{array}$ & $\begin{array}{c}\text { Chioggia } \\
\text { Max frequency }\end{array}$ & Mean frequency \\
\hline+80 & 39 times/year & 60 times/year $(1979)$ & 80 \\
+100 & 7 times/year & 19 times/year $(1979)$ & 15 times/year \\
+120 & once/year & 4 times/year $(1992)$ & 3 times/year \\
+140 & 1 in 6 years & once/year $(1979)$ & 1 in 3 years \\
+195 & 1 in 180 years & & 1 in 85 years \\
\hline
\end{tabular}

* with respect to Punta della Salute hydrometric zero.

In recent decades various long-term intervention plans to prevent, or at least minimize, the consequences of the high water have been proposed. These are the most important: a) to raise the lower lying areas of Venice and the other towns of the lagoon; this project is called insulae; b) to recover those barene converted to solid land and build up new ones; c) to open up the fish farm enclosures; d) to reduce the cross-section of the inlets connecting the lagoon with the sea and modify the end sections of the breakwaters; e) to refill the Oil Canal (Canale dei Petroli); f) to fit mobile gates to the inlets between the lagoon and the sea.

In 1997 an international group of experts was appointed by the Italian Government to review the proposals for intervention and in particular the mobile gates project, its effectiveness against exceptional high tides would be about 12 times with a total closure of 42 hours. Consequently, the total duration of the lagoon's isolation from the sea would be too short to involve any damage to the lagoon ecosystem (Fig. 4).

Comparing the advantages and disadvantages of each proposal, the group of international experts concluded that Venice could be protected against exceptional episodes of high water both by mobile gates located at the three inlets of the lagoon and by raising the low-lying parts of the urban centers to 100 centimeters above the reference level.

The ministeries of the Environment, Cultural Heritage and Public Works have examined and discussed these proposals and the advice of the international group of experts, but so far they have taken no final decision. 

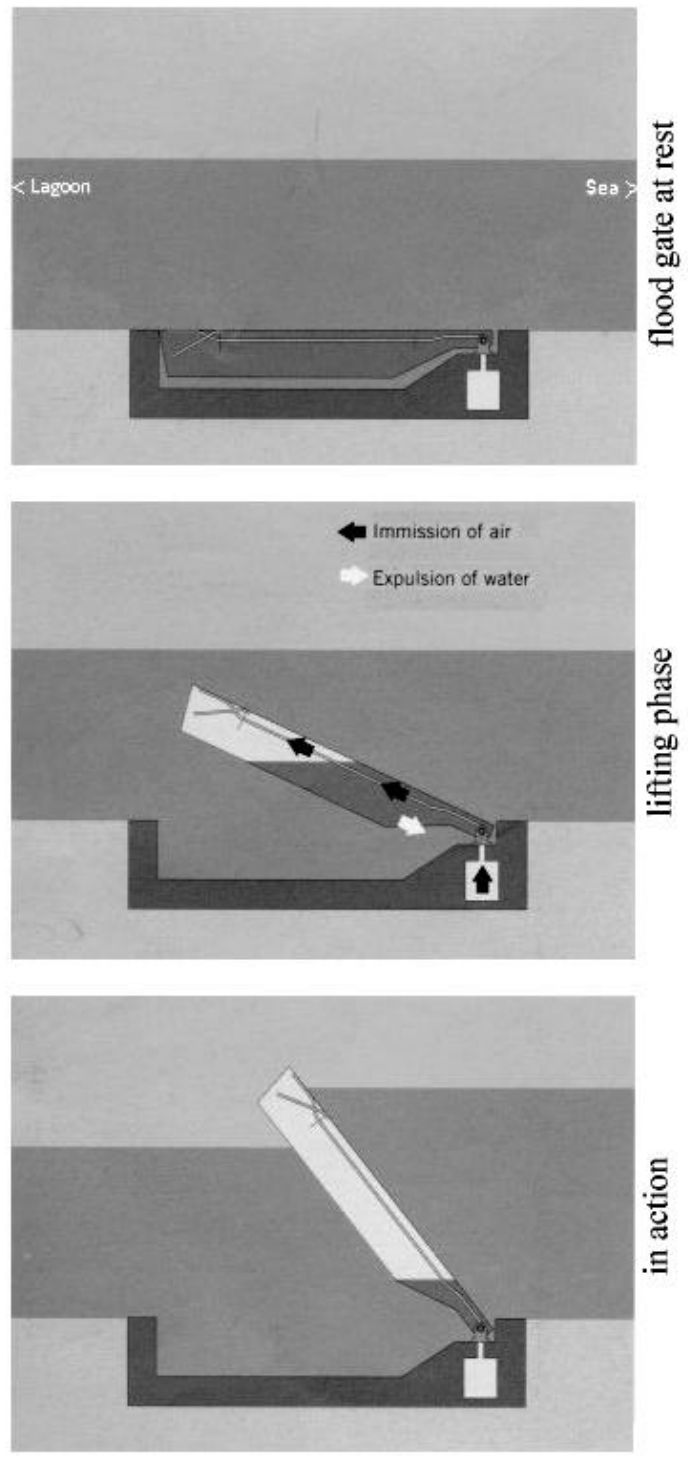

Fig. 4. Mobile flood barriers at lagoon inlets (Supplemento ai Quaderni Trimestrali Consorzio Venezia Nuova. Anno VI $\mathrm{n}^{\circ} 2$, aprile-giugno 1998).

\section{DISCUSSION AND CONCLUSIONS}

The Lagoon of Venice is a complex and unstable system profoundly influenced by the sea, the watershed and the atmosphere; there is a continuous and very active exchange of material and energy among these compartments. Biological production is very high and is enhanced by sewage and fertilizers. The dramatic proliferation of the macroalga Ulva rigida, and the control it exerted for several years on the community structure and the physical and chemical characteristics of the environment, are evidence of the poor capacity of the lagoon to maintain its ecological stability over time. In addition, there is a frequent active and passive immigration of allochthonous species, which influence to a greater or lesser extent the community structure of the lagoon. Any study on the lagoon must take into account the profound influence exerted by man and his activities through about ten centuries.

Before the Industrial Revolution, the objective of maintaining the lagoon's identity, against its ecological succession, was in harmony with the political and economic development of Venice; as a consequence, the city and the lagoon were strongly integrated. About two centuries ago, a conflict began to emerge between social and economic development and the conservation of the lagoon and the city of Venice. This contrast became sharper during the $30 \mathrm{~s}$ and the $60 \mathrm{~s}$ with the decision to locate an important industrial area on the lagoon border (Marghera) and to develop intensive agriculture in its watershed. This contrast has a precedent in the diatribe between Cristoforo Sabbadino and Alvise Cornaro at the beginning of the XVI century (Baschieri, 1996). The former supported the diversion outside the lagoon only of the most important rivers, but not the others, because they were useful in supplying freshwater to the lagoon and necessary to the surrounding marshes. Conversely, the latter maintained that all the water courses should be diverted, the marshes reclaimed, and the neighbouring barene cultivated.

The population of Venice decreased from 184,000 inhabitants in 1950 to less than 90,000 at the beginning of the 1990s; at present the resident population is reduced to 70,000 inhabitants, with an increasing percentage of old people. This demographic decline is due to various causes; one of the most important is the progressive reduction of industry with an attendant increase in unemployment. In addition, because of the state of decay of the houses, the increasing frequency of floods, the relatively high cost of living and the peculiar Venetian way of life, which is not always appreciated by the younger generation, increasing numbers of inhabitants are moving from the city to the urban centers of the terra firma, such as Mestre and Marghera. At present, tourism is Venice's most important economic resource, but also a major source of pollution, and negatively influences the quality of life of the inhabitants.

What will become of Venice and its lagoon in the future? What policies will best make it possible to reach the sustainable objectives for the future of Venice? Up to now there has been no agreement either on the objectives or on how to reach them (e.g., Zorzi 1992). There are several points of view on this problem between the following two extreme opinions: a) Any modification projected for Venice and the lagoon must be rejected, except for those proposing to destroy the works executed since the last century which have changed Venice from what it was at the time of the Serenissima Republic. This point of view does not take into account the fact that the Venetian Republic has continuously modified the city and its lagoon. b) Any changes proposed for bringing Venice into line with other cities must be applied and the lagoon area economically developed without considering the peculiarity of Venice and its 
environment. This is the way of thinking that supported the industrialization of Marghera and the introduction of intensive agriculture in the watershed.

In my opinion neither of these extreme attitudes is acceptable. The first does not face up to the real problems of Venice and would risk turning the city into a museum without Venetians. Since at present the mean ratio between the number of tourist presences and that of the inhabitants is about 160 , this hypothesis does not seem unwarranted. The second would progressively alter Venice and its environment, which are part of the common heritage of mankind.

The fate of Venice must be considered together with that of its lagoon, taking into account all the cultural, social, economic and environmental aspects involved. A modern development, not in conflict but in symbiosis with the tradition and nature of Venice, is required. First of all there is a need for economic restructuring of the activities of the city. Mass tourism, as presently organized, is an important economic resource, but negatively influences the urban environment and the quality of life of the Venetians, and is not without various disadvantages also for the tourists. It follows that tourism must be reorganized, regulated and extended to the lagoon environment. Cultural and craft activities should be encouraged, and service and non-polluting industries developed. In addition, if Venice is to survive as a city, it is essential to preserve the Venetian traditions and way of life, which are surely not in contrast with post-industrial development. This aim cannot be achieved without increasing opportunities for employment, providing housing and implementing a project of urgent, effective and long-term works to ameliorate the lagoon environment and protect Venice and the other urban centers against high water.

In conclusion, the old principle of establishing a symbiosis between the social-economic development of Venice and the conservation of its environment should be adopted and adapted to our time.

\section{REFERENCES}

Baschieri, P. 1996. Cenni generali sulla morfologia lagunare. In: Santarosa, L. (Ed.), La Laguna di Venezia. Filippi, Venezia: 25-30.

Bendoricchio, G. 1996. Carichi di nutrienti nella Laguna di Venezia e scenari di disinquinamento. In: Santarosa, L. (Ed.), La Laguna di Venezia. Filippi, Venezia: 75-79.

Brunelli, G. 1940. La pesca nella Laguna. In: Brunelli, G., Magrini, G., Miliani, L., Orsi, P. (Eds), La Laguna di Venezia, III (6). C. Ferrari, Venezia: 1-26.

Bullo, G. 1940a. Le valli salse da pesca. In: Brunelli, G., Magrini, G., Miliani, L., Orsi, P. (Eds), La Laguna di Venezia, III (6) C. Ferrari, Venezia: 27-48.

Bullo, G. 1940b. La vallicoltura. In: Brunelli, G., Magrini, G., Miliani, L., Orsi, P. (Eds), La Laguna di Venezia, III (6) C. Ferrari, Venezia: 49-212.

Camuffo, D. 1993. Analysis of the sea surges at Venice from A.D. 782 to 1990. Theoretical and Appl. Climatol., 47: 114.

Cecconi, G., P. Canestrelli, C. Corte \& M. Di Donato. 1998. Climate record of storm surges in Venice: RIBAMOD workshop, Impact of climate change on flooding and sustainable river management, Wallingford, 26-27 February, 1998.

Cesari, M. \& M. Pellizzato. 1985. Molluschi pervenuti in laguna di Venezia per apporti volontari o casuali. Acclimatazione di Saccostrea commercialis e di Tapes philippinarum. Boll. Malacologia, 21: 237-274.

Ciriacono, S. 1978. Per una storia dell'industria del lusso in Francia. La concorrenza italiana nei secoli XVI e XVII. Ricerche di Storia religiosa e sociale, 14: 181-202.

Ciriacono, S. 1995. Manifatture e mestieri in laguna: equilibri ambientali e sviluppo economico. In: Caniato, G., Turri, E., Zanetti, M. (Eds), La Laguna di Venezia, UNESCO, Cierre, Verona: 357-383.

Consiglio Regionale Veneto. 1998. Commissione Speciale per Venezia, Relazione sullo studio di impatto ambientale del progetto di massima degli interventi alle bocche lagunari per la regolazione dei flussi di marea. 15 maggio 1998.

Cossu, R. \& E. De Fraja Frangipane. 1985. Stato delle conoscenze sull'inquinamento della laguna di Venezia. $4^{\circ}$, Progetto Venezia, Min. LLPP, Magistrato alle Acque, Consorzio Venezia Nuova.

EIS. 1997. Environmental Impact Study for the preliminary design of the interventions at lagoon inlets for tidal flow control. Magistrato alle Acque e Consorzio Venezia Nuova, Venezia.

Orio, A.A. \& R. Donazzolo. 1987. Sostanze tossiche ed eutrofizzanti nella Laguna e nel Golfo di Venezia. Mem. Ist. Veneto Sc. Lett. Arti, 11: 149-215.

Pavoni, B., A. Marcomini, A. Sfriso, R. Donazzolo \& A.A. Orio. 1992. Changes in an estuarine ecosystem. The Lagoon of Venice as a case study. In: Dunnette, D.A., O'Brien, R.J. (Eds), ACS Symposium Series No 483, The Science of Global Change. American Chemical Society.

Pavoni, B., M. Salizzato \& A. Volpi Ghirardini. 1998. Organic micropollutants ( $\mathrm{PCB}, \mathrm{PAH}$, chlorinated pesticides) in sediments of Venice "rii". Chemical analyses and toxicity tests using Vibrio fischeri. Annali di Chimica, 88: 189200.

Pellizzato, M. 1996. Pesca e acquicoltura. In: Santarosa, L. (Ed.), La Laguna di Venezia. Filippi, Venezia: 59-64.

Perlin, I. 1991. A forest journey: the rôle of wood in the development of civilization. Penguin Books Canada Ltd.

Pignatti, S. 1962. Associazioni di alghe marine sulla costa veneziana. Mem. Ist. Veneto Sc. Lett. Arti, 32: 1-134.

Quaderni Trimestrali Consorzio Venezia Nuova (supplemento), Anno VI n 2, aprile-giugno 1998.

Rallo, G.P. 1992. I pesci e la pesca in laguna. In: Giordani Soika, A. (Ed.), La Laguna, tomo I, Corbo e Fiore, Venezia.

Ravagnan, G. 1980. Principi di progettazione di allevamenti ittici in acque salmastre. Nova Thalassia, 4 (suppl.): 203218.

Ravera, O. 1999. Aspetti ecologici delle valli da pesca della Laguna di Venezia. In: Realini, G.F. (Ed.), Le valli da pesca del comprensorio veneziano dal Tagliamento al Brenta. ENEA, Roma: 13-17.

Ravera, O., A. Piva \& S. Foltran. (2000). Chemical characteristics of the Palude della Rosa. In: Lasserre, P., Marzollo, A. (Eds), The Venice Lagoon Ecosystem: Inputs and Interactions between Land and Sea. Parthenon Publishing, Carnford, U.K.: (in press).

Ravera, O., N. Riccardi \& C. Targa. 1998. Oxygen consumption and release rates of weight, carbon, nitrogen, phosphorus and sulphur from dead Ulva rigida (C. Ag.) (Chlorophyta). Aquatic Ecology, 31: 325-331.

Regione Veneto, 1998. Piano per la prevenzione dell'inquinamento delle acque del bacino idrografico immediatamente sversante nella Laguna di Venezia. Segreteria Regionale dell'Ambiente. Venezia, Febbraio 1998. 
Report of the Committee of international experts. 1998. On the mobile gates project for the tidal flow regulation at the Venice Lagoon inlets. Quaderni Trimestrali Consorzio Venezia Nuova, Special issue, August 1998.

Rusconi, A. 1983. Il Comune marino a Venezia. Ministero dei Lavori Pubblici. Ufficio Idrografico del Magistrato alle Acque, Rapporto $\mathrm{N}^{\circ} 157$, Venezia.

Sfriso, A. 1987. Flora and vertical distribution of macroalgae in the Lagoon of Venice: a comparison with previous studies. Giornale Bot. Ital., 121: 69-85.

Solazzi, A., G. Orel, E. Chiozzotto, M. Scattolin, D. Curiel, F. Grim, E. Vio, F. Aleffi, D. Del Piero \& P. Vatta. 1991. Le alghe della Laguna di Venezia. I. Arsenale, Venezia.

Soriani, S., 1995a. Porto Marghera: il dibattito sulla localizzazione portuale. In: Caniato, G., Turri, E., Zanetti, M.
(Eds), La Laguna di Venezia. UNESCO, Cierre, Verona: 397-399.

Soriani, S. 1995b. Porto Marghera: la parabola della zona industriale. In: Caniato, G., Turri, E., Zanetti, M. (Eds), $L a$ Laguna di Venezia. UNESCO, Cierre, Verona: 400-403.

Zanetti, M., 1995a. La caccia in laguna. In: Caniato, G., Turri, E., Zanetti, M. (Eds), La Laguna di Venezia. UNESCO, Cierre, Verona: 311-327.

Zanetti, M. 1995b. Agricoltura lagunare: dall'autarchia alla produzione industriale. In: Caniato, G., Turri, E., Zanetti, M. (Eds), La Laguna di Venezia. UNESCO, Cierre, Verona. 331-337.

Zille, G.G. 1955. Morfologia della laguna. In: Magrini, G. (Ed.), La Laguna di Venezia, I (2). C. Ferrari, Venezia.

Zorzi, A., 1992. Idee europee per Venezia. Quaderni dell'Associazione Carlo Cattaneo di Lugano, 12-13.

Received: December 1999

Accepted: January 2000 